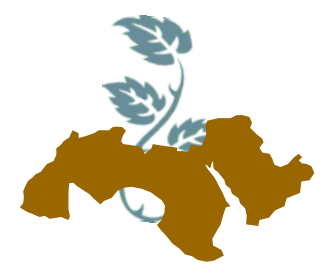

1473

Arab Univ.

J. Agric. Sci.,

Ain Shams Univ., Cairo

Special Issue, 26(2B), 1473-1482, 2018

\title{
EFFECT OF SOME NUTRIENTS ON GROWTH, YIELD AND FIBER QUALITY OF EGYPTIAN COTTON UNDER SALINE CONDITION
}

\author{
Amira S.E. Drwish ${ }^{1}$, Abd Rabou ${ }^{2}$ R.S., Zaky ${ }^{2}$ A.M. and Hamoda ${ }^{1}$ S.A.F.
}

1- Agronomy Res. Dept., Cotton Research Institute, Agric. Res. Cent., Giza, Egypt

2- Agronomy Dept., Fac. of Agric., Ain Shams Univ., Cairo, Egypt

Keywords: Cotton, Saline Water, Potassium Humate, Algex, Poly Ethylene Glycol, Potassein, Growth, Yield and Fiber Quality

\section{ABSTRACT}

Two pot experiments were carried out at the greenhouse of the Cotton Research Institute, Agric. Res. Cent., Giza, Egypt during 2015 and 2016 seasons to study the response of cotton plant to application of some nutrients to improve the performance of cotton plant under irrigation of saline water to increase growth, yield and yield components and fiber quality of Giza 90 cotton cultivar. The experimental design was a split plot design with four replications. Main plots included saline water solutions treatments (control, 2000, 4000, 6000 and 8000 ppm), sub plot included four nutrients application (Potassium Humate, Algex, Poly Ethylene Glycol (PEG) 6000 and Potassein compared with control). The obtained results could be summarized as follows: Irrigation with saline water over seasons significantly decreased plant height, number of fruiting branches/plant, number of open bolls /plant, boll weight, seed index, seed cotton yield per plant, fiber length, uniformity index, fiber strength and micronaire value, while, lint \% was significantly increased. Nutrients application had significant effect on growth parameters, yield and its components and fiber properties under study, All nutrients treatments gave the highest values of growth parameters, yield and its components and fiber properties as compared with the control in both seasons. In general, plants sprayed with PEG gave the highest averages of plant height, number of fruiting branches/plant. Potassium Humate gave the highest averages of yield and its components and fiber properties followed by plants sprayed with Algex, while the plants sprayed with PEG as came the last in these respect in both seasons. Interaction between irrigation with slain water and nutrients application by salinity tolerance inducers had a significant effect on plant height, number of fruiting branches per plant, boll weight, number of open bolls /plant, seed index, seed cotton yield /plant and fiber quality under study in both seasons. Plants treated with foliar nutrients under salinity condation scored the highest average of growth parameters, yield and its components and fiber properties. Potassium Humate, Algex, PEG and Potassein applications to plants under normal and salinity conditions had positive effects on improving the performance of cotton plants, which increased plant growth and yield especially under salinity conditions.

\section{INTRODUCTION}

Water availability for irrigation could be enhanced through judicious and proper use of saline water and the recycling of drainage waters. Considerable amounts of such water are available in various places in the world. With the use of improved farming and management practices. The development of crops by increased salt tolerance and the adoption of new crop and water management strategies will further enhance and facilitate the use of saline waters for irrigation and crop production, while keeping soil salinity from becoming excessive. Use of saline water for irrigation requires standard management practices including selection of appropriate crops and crop rotations, 
improvement in water and soil management and in some cases the adoption of advanced irrigation technology and improvement of the drainage conditions in the irrigated areas. Use of saline water in irrigated became an important mean for alleviating water scarcity in arid and semi-arid regions. Irrigation with saline water had significant effect on cotton yield components, while irrigation with saline water at seedling or flowering led to decrease number of open bolls per plant, boll weight, seed index, lint $\%$ and seed cotton yield/plant Abdel-Al and Syiam (1999). Irrigation with saline water significantly decreased plant height, number of fruiting branches, total number of bolls and open bolls, boll weight, seed index, lint \% and seed cotton yield per plant Saeed, (2000). While irrigation with water salinity had bad effect on many soil physicochemical properties and significantly reduced cotton biomass, $\mathrm{N}$ uptake and yield Min, et al (2016).

Humic acids use as complement to synthetic or organic fertilizers. In many instances, regular humic acids use will reduce the need for fertilization due to the soil and plant ability to make better use of it. Humates have long been used as a soil conditioner; fertilizer and soil supplement, humic acid can be used as growth regulate-hormone improve plant growth and enhance stress tolerance (Albayrak and Camas, 2005). Basbag, (2008) found that different humic acid treatments (seed soaking, foliar spray, seed soaking + foliar spray) significantly affected number of sympodial branches, plant height, number of bolls and seed cotton yield, and had no significant effect on lint \%, fiber length, fiber fineness and fiber strength. Haroon et al (2010) found that application of $0.5,1$ and $2 \mathrm{~kg} / \mathrm{ha}$ humic acid increased seed cotton yield. Humex application to plants under normal and water stress conditions could induce drought tolerance of cotton plants and in turn improved plant growth, fruiting and yield particularly under water stress and high temperature conditions (Hamoda, 2012). Gebaly (2012) found that the highest seed cotton yield/fed. and its components were obtained with application of soil potassium humate $4 \mathrm{~kg} / \mathrm{fed}$. + spraying cotton plants with potassium humate $2 \mathrm{~g} / \mathrm{L}$ ). Also, she found that the application of potassium humate showed significantly increased number of sympodia, opened bolls/plant, boll weight and seed cotton yield/fed. Emara and Hamoda (2012) and Abou-Zaid et al (2013) found that the tallest plants and the highest number of sympodia/plant, number of open bolls/plant, boll weight, seed cotton yield/fed. were produced from foliar spraying of humex $5 \mathrm{~cm}^{3} / \mathrm{L}$ three times.
About 9,000 macro algae species are classified into three main groups depending on the pigmentation including brown, green and red algae. Seaweeds among the alga are used in the agriculture (Hong et al 2007). More than 15 million tons of seaweeds are produced annually and used as biofertilizer in agriculture and also used human food, animal feed and row material for industry (FAO, 2006). Some chemical analysis revealed that seaweeds extracts have all major and minor nutrients, and all trace elements; aliginic, amino acid, vitamins, auxins (Zhang and Ervin, 2008). Seaweeds and their extracts have been used in many countries as soil conditioners, crop growth, and increase the yield, yield components (Sabir et al 2014) enhance seed germination, seedling vigor (Economou et al 2007) and increase uptake of nutrients, ripening of fruits, increases shelf-life of the produce, and resistance to fungal diseases such as leaf stripe disease symptoms in grape (Calzarano, et al 2014). Many different beneficial effects have been also reported for crops treated with seaweed extract. It increases seed germination, root elongation, hypocotyls and leaf area when applied as foliar spray (Mantri and Chaugule, 2008). Shaaban, et al (2010) showed that the best concentrations of macronutrients were achieved by the algal extract treatments or the higher dose of the micronutrient fertilizer. However, the best uptake, nutrient balance and dry matter accumulation was recorded with combined algal extract and micronutrient fertilizer treatment.

Poly Ethylene Glycol (PEG) a non-penetrable and non-toxic osmotic lowers the water potential of the medium and has been used to simulate drought stress. PEG has been effectively mimic drought with various metabolic interference. Kaufman and Eckard (1971) found that PEG based in-vitro screening of drought tolerant plants germplasm in proven to be a significant method with good accuracy. Lawlor (1970) fount that PEG is a non-penetrating inert osmotic that lowers the osmotic potential of nutrient solutions, but it is not taken and is not phototoxic. Munir and Aftab (2009). Found that PEG pretreatment enhanced the biosynthesis of soluble protein contents. Likewise, a general increase was observed in antioxidant enzyme activity in the PEG-pretreated callus cultures, as compared to the non-pretreated controls exposed to the same salt concentration. PEG pretreatment also increased the regeneration potential of the callus cultures of both sugarcane cultivars after $\mathrm{NaCl}$ treatment. These results suggest 

under saline condition

that PEG 6000 pretreatment could improve salt tolerance in these 2 sugarcane cultivars.

Potassium is an essential macro-element required in large amounts for normal plant growth and development. Potassium is an important nutrient that has favorable effects on the metabolism of nucleic acids, proteins, vitamins and growth substances. Furthermore, Potassium plays important roles in the translocation of photsynthates, sugars and activation of many enzymes required from sources to sinks Morteza et al (2005). However, Pettigrew (1999) indicated that the elevated carbohydrate concentrations remaining in source tissue, such as leaves, appear to be part of the overall effect of potassium deficiency in reducing the amount of photosynthetic available for reproductive sinks and thereby producing changes in the yield and quality of cotton. Many studies have shown increased yield and productivity in response to potassium fertilization as reported by Sharma and Sundar (2007), Abou-Zaid et al (2009), Emara and Hamoda (2012), Gomaa et al (2014), AbdelAal et al (2014 and 2015) and Emara (2014 and 2015).

The main objective of this investigation was to study the response of cotton plant to application of some nutrients under salinity condition to improve the performance of cotton plants and increase growth, yield and yield components and fiber quality of Giza 90 cotton cultivar.

\section{MATERIALS AND METHODS}

Two pot experiments were carried out at the greenhouse of the Cotton Research Institute, Agric. Res. Cent., Giza, Egypt during 2015 and 2016 seasons to study the response of cotton plant to application of some nutrients under salinity condition to improve the performance of cotton plants and increase growth, yield and yield components and fiber quality of Giza 90 cotton cultivar. The experimental design was a split-plot with four replications. Main plots included five salinity levels (control, 2000, 4000, 6000, 8000 ppm), while sub plot included four nutrient applications Potassium Humate (Potassium humate $85 \%$ + Potassium $8 \%$ + Fulvic Acid 3\%) $5 \mathrm{~cm} /$ later, Algex (Alges species $+10 \%$ Potassium) $3 \mathrm{~cm} /$ later, Poly Ethylene Glycol (PEG) $6000\left(\mathrm{C}_{2 n} \mathrm{H}_{4 n}+\mathrm{O}_{n}+1\right) 2 \%$ and Potassein $\left(30 \%\right.$ Potassium Oxide $\left(\mathrm{K}_{2} \mathrm{O}\right)+5 \%$ Superphosphate $\left.\left(\mathrm{P}_{2} \mathrm{O}_{5}\right)\right) 4 \mathrm{~cm} /$ later compared with control (untreated plants).
The nutrients application was sprayed three times at squaring, beginning of flowering and 2 weeks later. Seeds were sown in pots $(40 \mathrm{~cm}$ in diameter filled with clay loam textured soil) on April $15^{\text {th }}$ and April $12^{\text {th }}$ in 2015 and 2016 seasons, respectively. Cotton plant thinned after complete emergence (35 day from planting) to two plants /pot. All pots received Phosphorus fertilizer as ordinary superphosphate $\left(15.5 \% \mathrm{P}_{2} \mathrm{O}_{5}\right)$ at the rate of $22.5 \mathrm{~kg} \mathrm{P}_{2} \mathrm{O}_{5} /$ fed. during seed bed preparation. Nitrogen fertilizer in the form of ammonium nitrate $(33.5 \% \mathrm{~N})$ at the rate of $60 \mathrm{Kg} \mathrm{N} / \mathrm{fed}$. was applied in two equal doses, immediately before the first and the second irrigations. Potassium fertilizers in the form of potassium sulfate $\left(48 \% \mathrm{~K}_{2} \mathrm{O}\right)$ at the rate of $24 \mathrm{~kg} \mathrm{~K} \mathrm{~K}_{2} \mathrm{O} / \mathrm{fed}$. was side-dressed in a single dose before the second irrigation. Normal agricultural practices were followed throughout the growing seasons. Samples were collected at random from each sub plot in order to study growth and yield traits. Irrigation with tap water until the first irrigation after sowing was used. Hence forward plants were irrigated with saline solutions of 2000 , 4000,6000 and 8000 ppm $\mathrm{NaCl}$ during the whole season, while untreated pots (control) were irrigated with tap water continuously.

At harvest, samples were randomly collected from each pot to estimate plant height $(\mathrm{cm})$, number of fruiting branches/plant, number of open bolls/plant, boll weight $(\mathrm{gm})$, lint $\%$, seed index (gm) and seed cotton yield per plant (gm). Fiber length in millimeter at $2.5 \%$ span length and uniformity index were determined by the digital Fibrograph according to the standard method for testing the fiber length (A.S.T.M. 1447-63) A.S.T.M. (2012), fiber fineness expressed as Micronaire instrument reading (A.S.T.M.D-1448-59)) and fiber strength (It was measured for flat-bundles of fiber using the Pressley tester at zero gauge length, and recorded as (Pressley index) values (A.S.T.M.D1445-67). All fiber properties tested in the laboratories of the Cotton Technology Research Division, Cotton Research Institute. Representative soil samples were taken before planting in the two seasons and were prepared for analysis, according to Chapman and Pratt (1978). Results of soil analysis are shown in Table (1). All collected data were subjected to statistical analysis as proposed by Gomez and Gomez (1984) and means were compared by LSD at $5 \%$ level of probability. 
Table 1. Soil analysis of the soil used in the experiment in 2015 and 2016 seasons

\begin{tabular}{|c|c|c|c|c|c|c|c|c|c|c|c|c|}
\hline \multirow{3}{*}{ Seasons } & \multicolumn{12}{|c|}{ Properties } \\
\hline & \multirow{2}{*}{ Texture } & \multirow{2}{*}{$\mathrm{pH}$} & \multirow{2}{*}{$\begin{array}{l}\text { EC Mmhos } \\
/ \mathrm{cm} .\end{array}$} & \multirow{2}{*}{$\begin{array}{c}\mathrm{CaCO}_{3} \\
\%\end{array}$} & \multicolumn{8}{|c|}{ Available element ppm } \\
\hline & & & & & $\mathbf{N}$ & $\mathbf{P}$ & $\mathrm{K}$ & $\mathrm{Fe}$ & Mn & $\mathrm{Zn}$ & $\mathrm{Cu}$ & B \\
\hline 2015 & $\begin{array}{l}\text { Clay } \\
\text { loam }\end{array}$ & 7.4 & 0.26 & 2.9 & 64 & 11 & 385 & 12.4 & 16.4 & 2.2 & 4.0 & 0.45 \\
\hline 2016 & $\begin{array}{l}\text { Clay } \\
\text { loam }\end{array}$ & 7.6 & 0.22 & 3.1 & 61 & 10 & 336 & 13.5 & 8.6 & 1.7 & 3.3 & 0.40 \\
\hline
\end{tabular}

\section{RESULTS AND DISCUSSION}

The effect of irrigation by saline water, nutrients application and its interaction on growth parameter, yield and its components and fiber quality of Giza 90 cotton cultivar during 2015 and 2016 seasons showed in Tables (2 to 4).

Effect of irrigation by saline water on growth parameters, yield and its components and fiber quality of Giza 90 cotton variety.

Data in Table (2) reveal that increasing salinity levels in irrigation water from $2000 \mathrm{ppm}$ to 8000 ppm significant decreased plant height, number of fruiting branches/plant, as compared with the control. The reduction in plant growth in case of salinity could be in part due to limit plant ability to absorb nutrients needed for optimal growth and development of the plant. Salinity effects on the major physiological and biochemical processes that regulate growth such as photosynthesis, protein synthesis, and lipid metabolism etc., salt induced reduction in growth is generally attributable to: saltinduced osmotic stress (water deficit), specific ion effect, nutritional imbalance, hormonal imbalance and salt-induced oxidative stress (Munns and Tester, 2008). Also, data presented in Table (3) show that salinity levels had a significant effect on boll weight, number of open bolls/plant, lint \%, seed index and seed cotton yield /plant in both seasons. Increasing salinity levels from 2000ppm to $8000 \mathrm{ppm}$ significantly decreased number of open bolls /plant, boll weight, seed index and seed cotton yield/plant, while lint \% was significantly increased. Similar results were obtained by Abdel -Al and Syiam (1999), Saeed, (2000) and Min, et al (2016). Data presented in Tables (4) show that irrigation by saline water had a significant effect on fiber length, uniformity index, strength and micronaire reading in both seasons. By increasing salinity levels significantly decreased fiber length and strength. Abdel-Al and Syiam (1999) came to same conclusion.

Effect of nutrients application on growth parameter, yield and its components and fiber quality of Giza 90 cotton variety.

Data in Table (2) reveal that the nutrients application Potassium Humate, Algex, Poly Ethylene Glycol and Potassein showed significant increase in plant height and number of fruiting branches /plant as compared with untreated plants in both seasons. In general, plants which sprayed with PEG gave the highest averages of growth parameters followed by potassium humate. Similar results were obtained by Munir and Aftab (2009). So humates have long been used as a soil conditioner; fertilizer and soil supplement, humic acid can be used as growth regulate-hormone improve plant growth and enhance stress tolerance (Albayrak and Camas, 2005). Data in Table (3) show that the nutrients (salinity tolerance inducers) had a significant effect on number of open bolls /plant, boll weight, seed index, lint $\%$ and seed cotton yield /plant in both seasons. All nutrients i.e. Potassium Humate, Algex, Poly Ethylene Glycol and Potassein showed significant increase in yield and its components (boll weight and number of open bolls per plant) as compared with untreated plants in both seasons, except lint \% decreases. In general, plants sprayed with Potassium Humate gave the highest averages of yield and its components, followed by plants sprayed with Algex, while the plants sprayed with Poly Ethylene Glycol came the last in these respects in both seasons. The positive effect of foliar feeding Potassium Humate (contain $\mathrm{K}$ ) for most traits of yield and its components may be due to that $\mathrm{K}$ is involved in many processes in the plant such as photosynthesis, respiration, carbohydrate metabolism, translocation and protein 

under saline condition

Table 2. Effect of irrigation by saline water (A), nutrients application (B) and its interaction on cotton growth traits of Giza 90 cotton cultivar in 2015 and 2016 seasons

\begin{tabular}{|c|c|c|c|c|c|}
\hline \multicolumn{2}{|c|}{ Treatments } & \multicolumn{2}{|c|}{$\begin{array}{l}\text { Plant height at harvest } \\
(\mathrm{cm})\end{array}$} & \multicolumn{2}{|c|}{$\begin{array}{c}\text { Number of fruiting } \\
\text { branches /plant }\end{array}$} \\
\hline $\begin{array}{c}\text { Irrigation by } \\
\text { saline water (A) }\end{array}$ & $\begin{array}{l}\text { nutrients application } \\
\text { (B) }\end{array}$ & 2015 & 2016 & 2015 & 2016 \\
\hline \multirow{5}{*}{ Control } & Control & 121.25 & 131.00 & 11.25 & 13.00 \\
\hline & Potassium Humate & 128.75 & 139.00 & 12.50 & 14.00 \\
\hline & Algex & 126.50 & 133.00 & 11.75 & 14.00 \\
\hline & PEG & 140.00 & 152.00 & 13.25 & 14.75 \\
\hline & Potassein & 124.75 & 119.00 & 11.50 & 13.75 \\
\hline \multicolumn{2}{|r|}{ Mean } & 128.25 & 134.80 & 12.05 & 13.90 \\
\hline \multirow{5}{*}{2000 ppm } & Control & 104.00 & 110.00 & 11.10 & 12.25 \\
\hline & Potassium Humate & 115.00 & 122.00 & 12.00 & 12.75 \\
\hline & Algex & 110.00 & 119.00 & 11.75 & 12.50 \\
\hline & PEG & 119.00 & 125.00 & 12.50 & 13.00 \\
\hline & Potassein & 112.00 & 115.00 & 11.50 & 12.00 \\
\hline \multicolumn{2}{|r|}{ Mean } & 112.00 & 118.20 & 11.77 & 12.50 \\
\hline \multirow{5}{*}{4000 ppm } & Control & 94.00 & 100.00 & 9.75 & 11.00 \\
\hline & Potassium Humate & 104.00 & 115.00 & 11.50 & 11.50 \\
\hline & Algex & 107.00 & 113.00 & 10.25 & 11.50 \\
\hline & PEG & 110.00 & 116.00 & 11.75 & 12.00 \\
\hline & Potassein & 106.00 & 110.00 & 10.00 & 11.50 \\
\hline \multicolumn{2}{|r|}{ Mean } & 104.20 & 110.80 & 10.65 & 11.50 \\
\hline \multirow{5}{*}{6000 ppm } & Control & 72.25 & 75.00 & 8.75 & 10.00 \\
\hline & Potassium Humate & 83.00 & 95.00 & 10.50 & 10.50 \\
\hline & Algex & 84.50 & 90.00 & 10.25 & 11.25 \\
\hline & PEG & 93.25 & 100.00 & 11.00 & 11.25 \\
\hline & Potassein & 81.50 & 85.00 & 9.75 & 10.50 \\
\hline \multicolumn{2}{|r|}{ Mean } & 84.90 & 89.00 & 10.05 & 10.70 \\
\hline \multirow{5}{*}{8000 ppm } & Control & 62.25 & 67.00 & 7.75 & 8.50 \\
\hline & Potassium Humate & 72. 50 & 75.00 & 8.25 & 10.50 \\
\hline & Algex & 69.25 & 72.00 & 9.00 & 10.25 \\
\hline & PEG & 76.75 & 82.00 & 9.75 & 11.25 \\
\hline & Potassein & 65.50 & 70.00 & 8.75 & 9.75 \\
\hline \multicolumn{2}{|r|}{ Mean } & 69.25 & 73.20 & 8.90 & 10.05 \\
\hline \multirow{5}{*}{$\begin{array}{l}\text { General mean } \\
\text { of nutrients } \\
\text { application (B) }\end{array}$} & Control & 90.75 & 96.60 & 9.72 & 10.95 \\
\hline & Potassium Humate & 100.65 & 109.20 & 11.15 & 11.85 \\
\hline & Algex & 99.45 & 105.40 & 10.60 & 11.90 \\
\hline & PEG & 107.80 & 115.00 & 11.65 & 12.45 \\
\hline & Potassein & 97.95 & 99.80 & 10.50 & 11.50 \\
\hline \multirow{3}{*}{ LSD at 0.05 of } & A & 1.95 & 1.43 & 0.24 & 0.38 \\
\hline & B & 1.27 & 1.06 & 0.22 & 0.26 \\
\hline & AxB & 2.85 & 2.54 & 0.48 & 0.53 \\
\hline
\end{tabular}


Table 3. Effect of irrigation by saline water (A), nutrients application (B) and its interaction on cotton yield and its components of Giza 90 cotton cultivar in 2015 and 2016 seasons

\begin{tabular}{|c|c|c|c|c|c|c|c|c|c|c|c|}
\hline \multicolumn{2}{|c|}{ Treatments } & \multicolumn{2}{|c|}{$\begin{array}{l}\text { Number of } \\
\text { open bolls } \\
\text { per plant }\end{array}$} & \multicolumn{2}{|c|}{$\begin{array}{c}\text { Boll weight } \\
\text { (gm) }\end{array}$} & \multicolumn{2}{|c|}{$\begin{array}{l}\text { Seed index } \\
(\mathrm{gm})\end{array}$} & \multicolumn{2}{|c|}{$\begin{array}{l}\text { Lint } \\
\text { percentage }\end{array}$} & \multicolumn{2}{|c|}{$\begin{array}{l}\text { Seed cotton } \\
\text { yield per } \\
\text { plant (gm) }\end{array}$} \\
\hline $\begin{array}{l}\text { Irrigation } \\
\text { by saline } \\
\text { water (A) }\end{array}$ & $\begin{array}{c}\text { nutrients } \\
\text { applications } \\
\text { (B) }\end{array}$ & 2015 & 2016 & 2015 & 2016 & 2015 & 2016 & 2015 & 2016 & 2015 & 2016 \\
\hline \multirow{5}{*}{ Control } & Control & 10.00 & 10.25 & 2.15 & 2.37 & 10.20 & 9.43 & 35.85 & 35.96 & 22.77 & 24.48 \\
\hline & $\begin{array}{l}\text { Potassium } \\
\text { Humate }\end{array}$ & 11.50 & 12.00 & 2.33 & 2.44 & 10.32 & 10.65 & 35.30 & 35.50 & 28.75 & 30.12 \\
\hline & Algex & 11.25 & 11.75 & 2.30 & 2.41 & 10.31 & 10.66 & 35.44 & 35.65 & 26.87 & 28.19 \\
\hline & PEG & 10.00 & 10.75 & 2.23 & 2.39 & 10.25 & 10.46 & 35.70 & 35.80 & 23.12 & 24.66 \\
\hline & Potassein & 10.75 & 10.50 & 2.29 & 2.40 & 10.30 & 10.51 & 35.63 & 35.80 & 25.00 & 25.23 \\
\hline & Mean & 10.70 & 11.05 & 2.26 & 2.40 & 10.27 & 10.34 & 35.59 & 35.74 & 25.30 & 26.54 \\
\hline \multirow{5}{*}{2000 ppm } & Control & 9.50 & 10.25 & 2.25 & 2.30 & 9.89 & 10.25 & 36.88 & 36.10 & 21.12 & 22.40 \\
\hline & $\begin{array}{l}\text { Potassium } \\
\text { Humate }\end{array}$ & 11.00 & 11.50 & 2.26 & 2.39 & 10.15 & 10.45 & 35.71 & 35.65 & 24.97 & 27.21 \\
\hline & Algex & 10.50 & 11.00 & 2.27 & 2.40 & 10.10 & 10.37 & 35.80 & 35.73 & 24.27 & 26.06 \\
\hline & PEG & 9.75 & 10.25 & 2.14 & 2.26 & 9.90 & 10.33 & 36.21 & 36.00 & 21.80 & 22.33 \\
\hline & Potassein & 10.00 & 10.75 & 2.20 & 2.33 & 9.90 & 10.24 & 36.15 & 35.84 & 22.90 & 23.64 \\
\hline \multicolumn{2}{|r|}{ Mean } & 10.15 & 10.75 & 2.22 & 2.33 & 9.99 & 10.33 & 36.15 & 35.86 & 23.01 & 24.33 \\
\hline \multirow{5}{*}{4000 ppm } & Control & 8.00 & 8.75 & 2.16 & 2.20 & 9.73 & 10.15 & 36.85 & 36.30 & 15.82 & 18.16 \\
\hline & $\begin{array}{l}\text { Potassium } \\
\text { Humate }\end{array}$ & 10.25 & 10.50 & 2.14 & 2.28 & 10.05 & 10.38 & 35.80 & 35.85 & 22.17 & 24.08 \\
\hline & Algex & 10.00 & 10.75 & 2.10 & 2.24 & 10.05 & 10.31 & 35.89 & 35.95 & 21.75 & 23.74 \\
\hline & PEG & 8.50 & 8.25 & 2.00 & 2.14 & 9.80 & 10.17 & 36.81 & 36.11 & 17.05 & 17.77 \\
\hline & Potassein & 9.25 & 9.25 & 2.03 & 2.16 & 9.94 & 10.20 & 36.35 & 36.13 & 19.22 & 19.45 \\
\hline & Mean & 9.20 & 9.50 & 2.08 & 2.20 & 9.91 & 10.24 & 36.34 & 36.07 & 19.20 & 20.64 \\
\hline \multirow{5}{*}{6000 ppm } & Control & 7.25 & 7.75 & 1.80 & 1.86 & 9.46 & 9.79 & 37.53 & 36.55 & 14.00 & 14.60 \\
\hline & $\begin{array}{l}\text { Potassium } \\
\text { Humate }\end{array}$ & 9.50 & 10.00 & 1.93 & 2.08 & 9.90 & 10.25 & 36.91 & 35.63 & 18.00 & 20.01 \\
\hline & Algex & 9.00 & 9.50 & 1.90 & 2.05 & 9.86 & 10.20 & 36.99 & 36.00 & 17.85 & 19.12 \\
\hline & PEG & 8.00 & 8.50 & 1.76 & 1.90 & 9.79 & 9.98 & 37.31 & 36.32 & 13.77 & 15.58 \\
\hline & Potassein & 9.00 & 9.75 & 1.82 & 1.96 & 9.80 & 10.02 & 36.41 & 36.25 & 15.70 & 17.61 \\
\hline & Mean & 8.55 & 9.10 & 1.84 & 1.97 & 9.76 & 10.05 & 37.03 & 36.15 & 15.86 & 17.38 \\
\hline \multirow{5}{*}{8000 ppm } & Control & 6.00 & 6.75 & 1.70 & 1.80 & 8.82 & 9.00 & 37.74 & 37.10 & 10.95 & 12.05 \\
\hline & $\begin{array}{l}\text { Potassium } \\
\text { Humate }\end{array}$ & 7.25 & 7.25 & 1.81 & 1.97 & 9.37 & 9.20 & 37.21 & 36.31 & 14.25 & 14.84 \\
\hline & Algex & 7.50 & 7.25 & 1.79 & 1.95 & 9.28 & 9.13 & 37.33 & 36.34 & 13.65 & 14.25 \\
\hline & PEG & 7.00 & 7.75 & 1.63 & 1.77 & 9.20 & 9.01 & 37.61 & 36.90 & 11.72 & 13.17 \\
\hline & Potass & 7.00 & 7.75 & 1.72 & 1.87 & 9.26 & 9.09 & 37.41 & 36.53 & 12.62 & 13.99 \\
\hline \multicolumn{2}{|r|}{ Mean } & 6.95 & 7.35 & 1.73 & 1.87 & 9.18 & 9.08 & 37.46 & 36.64 & 12.64 & 13.65 \\
\hline \multirow{5}{*}{$\begin{array}{c}\text { General } \\
\text { mean of } \\
\text { nutrients } \\
\text { application } \\
\text { (B) }\end{array}$} & Control & 8.15 & 9.75 & 2.01 & 2.10 & 9.62 & 9.72 & 36.97 & 36.40 & 16.93 & 18.33 \\
\hline & $\begin{array}{l}\text { Potassium } \\
\text { Humate }\end{array}$ & 9.90 & 10.25 & 2.09 & 2.23 & 9.96 & 10.18 & 36.19 & 35.79 & 21.63 & 23.25 \\
\hline & Algex & 9.65 & 10.05 & 2.07 & 2.21 & 9.92 & 10.13 & 36.29 & 35.93 & 20.88 & 22.27 \\
\hline & PEG & 8.65 & 9.10 & 1.95 & 2.09 & 9.79 & 9.99 & 36.73 & 36.23 & 17.49 & 18.70 \\
\hline & Potassein & 9.20 & 9.60 & 2.01 & 2.14 & 9.84 & 10.01 & 36.39 & 36.11 & 19.09 & 19.99 \\
\hline \multirow{3}{*}{$\begin{array}{c}\text { LSD at } 0.05 \\
\text { of }\end{array}$} & A & 0.23 & 0.32 & 0.06 & 0.03 & 0.04 & 0.09 & 0.31 & 0.25 & 0.60 & 1.41 \\
\hline & B & 0.27 & 0.34 & 0.08 & 0.02 & 0.03 & 0.10 & 0.33 & 0.29 & 0.43 & 0.51 \\
\hline & $A \times B$ & 0.61 & 0.78 & 0.12 & 0.05 & 0.07 & 0.23 & 0.49 & 0.54 & 0.96 & 1.12 \\
\hline
\end{tabular}



under saline condition

Table 4. Effect of irrigation by saline water, nutrients application and its interaction on cotton fiber properties of Giza 90 cotton cultivar in 2015 and 2016 seasons

\begin{tabular}{|c|c|c|c|c|c|c|c|c|c|}
\hline \multicolumn{2}{|c|}{ Treatments } & \multicolumn{2}{|c|}{ Fiber length } & \multicolumn{2}{|c|}{$\begin{array}{l}\text { Uniformity } \\
\text { index }\end{array}$} & \multicolumn{2}{|c|}{ Fiber strength } & \multicolumn{2}{|c|}{$\begin{array}{l}\text { Micronare } \\
\text { value }\end{array}$} \\
\hline $\begin{array}{l}\text { Irrigation by } \\
\text { saline water } \\
\text { (A) }\end{array}$ & $\begin{array}{c}\text { nutrients } \\
\text { applications } \\
\text { (B) }\end{array}$ & 2015 & 2016 & 2015 & 2016 & 2015 & 2016 & 2015 & 2016 \\
\hline \multirow{5}{*}{ Control } & Control & 29.90 & 30.75 & 82.30 & 83.20 & 10.47 & 10.32 & 4.40 & 4.20 \\
\hline & $\begin{array}{l}\text { Potassium } \\
\text { Humate }\end{array}$ & 31.03 & 31.70 & 84.52 & 83.60 & 11.02 & 11.40 & 4.80 & 4.55 \\
\hline & Algex & 30.88 & 31.33 & 84.25 & 84.50 & 10.91 & 11.20 & 4.70 & 4.50 \\
\hline & PEG & 30.30 & 30.91 & 83.52 & 82.15 & 10.52 & 10.89 & 4.32 & 4.15 \\
\hline & Potassein & 30.67 & 31.30 & 84.22 & 84.15 & 10.75 & 11.07 & 4.65 & 4.40 \\
\hline \multicolumn{2}{|r|}{ Mean } & 30.55 & 31.20 & 83.76 & 83.52 & 10.73 & 10.98 & 4.57 & 4.36 \\
\hline \multirow{5}{*}{2000 ppm } & Control & 29.23 & 30.61 & 81.70 & 82.12 & 10.22 & 10.12 & 4.25 & 4.20 \\
\hline & $\begin{array}{l}\text { Potassium } \\
\text { Humate }\end{array}$ & 30.45 & 31.18 & 83.62 & 83.77 & 10.80 & 10.80 & 4.80 & 4.60 \\
\hline & Algex & 30.33 & 30.92 & 83.47 & 83.32 & 10.70 & 10.64 & 4.62 & 4.67 \\
\hline & PEG & 30.00 & 30.49 & 82.07 & 81.20 & 10.47 & 10.41 & 4.52 & 4.30 \\
\hline & Potassein & 30.25 & 30.85 & 83.25 & 82.60 & 10.57 & 10.50 & 4.35 & 4.50 \\
\hline \multicolumn{2}{|r|}{ Mean } & 30.05 & 30.81 & 82.82 & 82.60 & 10.55 & 10.49 & 4.51 & 4.45 \\
\hline \multirow{5}{*}{4000 ppm } & Control & 28.23 & 30.42 & 81.05 & 81.10 & 10.14 & 10.67 & 4.15 & 4.07 \\
\hline & $\begin{array}{l}\text { Potassium } \\
\text { Humate }\end{array}$ & 30.13 & 30.78 & 82.85 & 83.25 & 10.65 & 10.37 & 4.65 & 4.30 \\
\hline & Algex & 29.81 & 30.61 & 82.70 & 83.05 & 10.52 & 10.16 & 4.42 & 4.20 \\
\hline & PEG & 29.65 & 30.50 & 80.92 & 82.05 & 10.35 & 9.72 & 4.25 & 4.22 \\
\hline & Potassein & 29.77 & 30.54 & 81.85 & 82.45 & 10.41 & 10.28 & 4.30 & 4.07 \\
\hline \multicolumn{2}{|r|}{ Mean } & 29.51 & 30.57 & 81.87 & 82.38 & 10.41 & 10.24 & 4.35 & 4.17 \\
\hline \multirow{5}{*}{6000 ppm } & Control & 28.50 & 29.80 & 80.77 & 82.15 & 9.10 & 9.25 & 4.05 & 3.62 \\
\hline & $\begin{array}{l}\text { Potassium } \\
\text { Humate }\end{array}$ & 29.58 & 30.47 & 81.32 & 83.17 & 9.40 & 10.07 & 4.57 & 4.05 \\
\hline & Algex & 29.26 & 30.34 & 81.55 & 82.07 & 9.25 & 9.72 & 4.55 & 4.07 \\
\hline & PEG & 28.65 & 30.47 & 80.92 & 80.15 & 9.15 & 9.40 & 4.30 & 3.95 \\
\hline & Potassein & 29.05 & 30.20 & 81.65 & 81.17 & 9.15 & 9.65 & 4.37 & 4.07 \\
\hline \multicolumn{2}{|r|}{ Mean } & 29.01 & 30.26 & 81.24 & 81.74 & 9.21 & 9.62 & 4.37 & 3.95 \\
\hline \multirow{5}{*}{8000 ppm } & Control & 28.49 & 29.30 & 80.07 & 80.12 & 8.20 & 8.60 & 4.05 & 3.90 \\
\hline & $\begin{array}{l}\text { Potassium } \\
\text { Humate }\end{array}$ & 29.40 & 30.30 & 81.42 & 82.15 & 9.30 & 9.40 & 4.50 & 4.05 \\
\hline & Algex & 29.18 & 29.90 & 80.67 & 81.07 & 9.37 & 9.15 & 4.35 & 3.65 \\
\hline & PEG & 29.59 & 29.40 & 80.30 & 80.10 & 8.40 & 9.05 & 3.80 & 3.75 \\
\hline & Potassein & 28.80 & 29.74 & 80.27 & 80.32 & 8.65 & 9.10 & 4.15 & 4.15 \\
\hline \multicolumn{2}{|r|}{ Mean } & 29.09 & 29.73 & 80.55 & 80.75 & 8.78 & 9.06 & 4.17 & 3.90 \\
\hline \multirow{5}{*}{$\begin{array}{l}\text { General mean } \\
\text { of nutrients } \\
\text { application } \\
\text { (B) }\end{array}$} & Control & 28.87 & 30.18 & 81.18 & 80.74 & 9.62 & 9.79 & 4.18 & 4.00 \\
\hline & $\begin{array}{l}\text { Potassium } \\
\text { Humate }\end{array}$ & 30.12 & 30.89 & 82.75 & 83.19 & 10.23 & 10.41 & 4.66 & 4.31 \\
\hline & Algex & 29.89 & 30.62 & 82.53 & 82.80 & 10.15 & 10.17 & 4.53 & 4.22 \\
\hline & PEG & 29.64 & 30.35 & 81.55 & 81.13 & 9.78 & 9.89 & 4.24 & 4.07 \\
\hline & Potassein & 29.71 & 30.53 & 82.25 & 82.14 & 9.90 & 10.12 & 4.36 & 4.24 \\
\hline \multirow{3}{*}{ LSD at 0.05 of } & A & 0.03 & 0.09 & 0.18 & 0.09 & 0.06 & 0.03 & 0.06 & 0.09 \\
\hline & B & 0.02 & 0.08 & 0.31 & 0.08 & 0.02 & 0.05 & 0.05 & 0.11 \\
\hline & $\mathrm{AxB}$ & 0.05 & 0.19 & 0.67 & 0.22 & 0.04 & 0.14 & 0.14 & 0.22 \\
\hline
\end{tabular}


synthesis (Hearn, 1981). Similar results were obtained by Hamoda, (2012), Gebaly (2012), Emara and Hamoda (2012) and Abou-Zaid et al (2013). (El-Din, 2015) found that many beneficial effects had been also reported for crops treated with seaweed extract. In general using foliar nutrients under salinity stress improving the performance of plant growth which led to the good yielding. Data in Table (4) also show that studied nutrients treatments had a significant effect of fiber length, fiber strength and micronaire value in both seasons. All nutrients treatments (Potassium Humate, Algex, poly Ethylene glycol and Potassein) gave the best averages for the fiber length, fiber strength and micronaire reading compared with the untreated plants. In general, plants which sprayed with Potassium Humate gave the highest values of fiber length, uniformity index and strength in both seasons.

Effect of the interaction between irrigation by saline water and nutrients application on growth parameters, yield and its components and fiber quality of Giza 90 cotton variety.

Data presented in Tables (2, 3 and 4) showed that the interaction between salinity levels by irrigation with saline water and nutrients application had a significant effect on plant height, number of fruiting branches/plant, boll weight, number of open bolls/plant, seed index and seed cotton yield /plant, lint \%, fiber length, uniformity index, fiber strength and micronaire value in both season. The plants which were treated with foliar nutrients under salinity stress gave the highest averages of plant height, boll weight, number of open bolls/plant, seed index and seed cotton yield/plant, The Potassium Humate, Algex, Poly Ethylene Glycol and Potassein applications under normal and salinity stress conditions had positive effects on improving the performance of cotton plants, which increased plant growth and yield especially under salinity stress conditions.

\section{REFERENCES}

Abdel-Al, M.H. and Syiam, M.M. 1999. Effect of irrigation with saline water in two types of soil on growth, yield, yield components and fiber quality of Giza 75 cotton variety. Agric. Res. Rev., 68(6), 1155-1169.

Abdel-Aal, Amal, S.A., Emara, M.A.A. and Hamoda, S.A.F. 2015. Effect of times and methods of potassium fertilizer on yield and yield com- ponents of new hybrid cotton (Giza 86 x 10229) under early and late sowing. Fayoum J. Agric. Res. \& Dev., 30(1), 13 - 26.

Abdel-Aal, Amal, S.A., Hamoda, S.A.F. and Ibrahim, M.A.A. 2014. Effect of different sources of potassium on growth and productivity of cotton. Egypt. J. of Appl. Sci., 29 (11), 562 572.

Abou-Zaid, M.K., Emara, M.A. and Hamoda, S.A.F. 2009. Future of Egyptian cotton production in the newly reclaimed desert land of Egypt: 10- Cotton response to soil, foliar potassium application and potassium dissolving bacteria (KDB). J. Adv. Agric. Res., Fac. Agric. Saba Basha, 42(1), 73-80.

Abou-Zaid, M.K., Emara, M.A. and Hamoda, S.A.F. 2013. Effect of humex and biofertilization on growth, yield and quality of cotton under calcareous soil conditions. The $2^{\text {nd }}$ Alexandria Inter. Cotton Conf., Fac. of Agric., Saba Basha, Alex. Univ., 10-11 April, 2013, Special Issue of J. Adv. Agric. Res. Fac. of Agric., Saba Basha, 1, 12 - 21.

Albayrak, S. and Camas, N. 2005. Efects of different levels and application times of humic acid on root and leaf yield and yield components of forage turnip (Brassica rapa L.). J. Agron., 4(2), 130-133.

A.S.T.M. 2012. American Society for Testing and Materials. Designation, Easton, MD, USA. 7(1), 20-32.

Basbag, S. 2008. Effects of humic acid application on yield and quality of cotton. (Gossybium hrisutum L). Asian J. of Chem., 20(3), 1961 1966.

Calzarano F., Di Marco, S., D'agostino, V., Schiff, S. and Mugnai, L. 2014. Grapevine leaf stripe disease symptoms (esca complex) are reduced by a nutrients and seaweed mixture. Phytopatho. Mediter., 53(3), 543-558.

Chapman, H.D. and Pratt, P.P. 1978. Methods of analysis for soils, plants and water. Univ. of California, Div. of Agric. Sci., Priced Publ., $4034 \mathrm{p}$.

Economou, G., Lyra, D., Sotirakoglou, K., Fasseas, K. and Taradilis, P. 2007. Stimulating Orobancheramosa seed germination with an Ascophyllumnodosum extract. Phytopar., 35, 367-375.

Emara, M.A. and Hamoda, S.A.F. 2012. Effect of humex on growth, yield and quality of cotton under calcareous soil conditions. The $1^{\text {st }}$ Alex. Inter. Cotton Conf., Fac. of Agric., Saba Basha, 

under saline condition

Alex. Univ., 17 - 18 April, Special Issue of $\mathbf{J}$. Adv. Agric. Res. Fac. of Agric., Saba Basha, 1,29 - 37.

Emara, M.A.A. 2014. Effect of some sources of potassium fertilizers on cotton production under calcareous soil conditions. Egypt. J. Appl. Sci., 29(11), 597-622.

Emara, M.A.A. 2015. Effect of potassium mineral and organic fertilizers on cotton productivity under calcareous soil conditions. The $3^{\text {rd }}$ Inter. Conf. of Environ. Studies and Res. Ins. "Natural Res. and Future Challenges", 23-25 Feb., 2015. J. Environ. Studies and Res., 2(Special Issue), pp. 27-41.

FAO. 2006. Yearbook of fishery statistics, 198(1-2), FAO, Rome.

Gebaly, Sanaa, G. 2012. Physiological effects of potassium forms and methods of application on cotton variety Giza 80. Egyptian J. Agric. Res., 90(4), 1633-1647.

Gomaa, M.A., Radwan, F.I., Ibrahim, I.A., Emara, M.A. and Kattosh, A.A. 2014. Response of Egyptian cotton to soil and foliar potassium application under calcareous soil conditions. J. Adv. Agric. Res., Fac. Agric., Saba Basha, 19(2), 236 - 246.

Gomez, K.A. and Gomez, A.A. 1984. Statistical procedures for agriculture research. $2^{\text {nd }} \mathrm{Ed}$., John Willey and Sons, New York, USA, pp. 1519.

Hamoda, S.A.F. 2012. Response of Giza 90 cotton cultivar to foliar application of some drought tolerance inducers under water stress and high temperature conditions in Upper Egypt. J. Plant Prod., Mansoura Univ., 3(3), 493-507.

Haroon, R., Khattak, R. and Muhammad, D. 2010. Seed cotton yield and nutrient concentrations as influenced by lignitic coal derived humic acid in salt affected soils. Sorhad $\mathbf{J}$. Agric., 26(1), 43-49.

Hearn, A.B. 1981. Cotton nutrition. Field Crop Abst. 34(1), 11-34.

Hong, D.D., Hien, H.M. and Son, P.N. 2007. Seaweeds from Vietnam used for functional food, medicine and bio-fertilizer. J. Appl. Phycol., 19, 817-826.

Kaufman, M.R. and Eckard, A.N. 1971. Evaluation of water stress control by polyethylene glycol by analysis of guttation. Plant Physiol., 47, 453-456.

Lawlor, D.W. 1970. Absorption of polyethylene glycols by plants and their effects on plant growth. New Phytol., 69, 501-513.
Mantri, V.A. and Chaugule, B.B. 2008. In-situ and ex-situ evaluation of seaweed liquid fertilizers on seed germination, early growth and chlorophyll content of Trigonella foenum graecum Linn. Proc. Nat. Acad. of Sci. India Sect. BBiol. Sci., 78 (2), 158-163.

Min, W., Guo, H.J., Zhang, W., Zhou, G.W., Ma, L.J., Ye, J. and Hou, Z.A. 2016. Irrigation water salinity and $\mathrm{N}$ fertilization: effects on ammonia oxidizer abundance, enzyme activity and cotton growth in a drip irrigated cotton field. J. Integ. Agric., 15(5), 1121-1131.

Morteza, M., Slaton, A., Evans, E., McConnell, J., Fred, M. and Kennedy, C. 2005. Effect of potassium fertilization on cotton yield and petiole potassium. Summaries of Arkansas Cotton Res., pp. 74 - 78.

Munir, N. and Aftab, F. 2009. The role of polyethylene glycol (PEG) pretreatment in improving sugarcane's salt ( $\mathrm{NaCl})$ tolerance, TUBITAK , Univ. Punjab, Pakistan, 33, 407-415.

Munns, R. and Tester, M. 2008. Mechanisms of salinity tolerance. Annu. Rev. Plant Biol., 59, 651-681.

Pettigrew, W.T. 1999. Potassium deficiency increases specific leaf weights of leaf glucose levels in field- grown cotton. Agron. J., 91, 962 - 968.

Sabir A., Yazar, K., Sabir, F.K., Kara, Z., Yazici, M.A. and Goksu, N. 2014. Vine growth, yield, berry quality attributes and leaf nutrient content of grapevines as influenced by seaweed extract (Ascophyllum nodosum) and nano size fertilizer pulverizations. Sci. Hort., 175, 1-8.

Saeed, M.A. 2000. Effect of irrigation with saline water on cotton plants of Giza 83 cultivar. Egypt. J. Agric. Res., 78(5), 2029-2046.

Shaaban, M. M., El-Saady, A.M. and El-Sayed, A.B. 2010. Green Microalgae Water Extract and Micronutrients Foliar Application as Promoters to Nutrient Balance and Growth of Wheat Plants. J. Amer. Sci., 6(9), 631-636.

Sharma, S. and Sundar, S. 2007. Yield, yield attributes and quality of cotton as influenced by foliar application of potassium. J. of Cott. Res. and Devel., 21, 51-54.

Zhang, X. and Ervin, E.H. 2008. Impact of seaweed extract-based cytokinins and zeatin riboside on creeping bentgrass heat tolerance. Crop Sci., 48, 364-370. 